\title{
OWNERSHIP STRUCTURE, PROFIT MAXIMIZATION, AND COMPETITIVE BEHAVIOR
}

\author{
Govert Vroom \\ Brian T. McCann
}


The Public-Private Sector Research Center is a Research Center based at IESE Business School. Its mission is to develop research that analyses the relationships between the private and public sectors primarily in the following areas: regulation and competition, innovation, regional economy and industrial politics and health economics.

Research results are disseminated through publications, conferences and colloquia. These activities are aimed to foster cooperation between the private sector and public administrations, as well as the exchange of ideas and initiatives.

The sponsors of the SP-SP Center are the following:

- Accenture

- Ajuntament de Barcelona

- Caixa Manresa

- Cambra Oficial de Comerç, Indústria i Navegació de Barcelona

- Departament d' Economia i Finances de la Generalitat de Catalunya

- Departament d' Innovació, Universitats i Empresa de la Generalitat de Catalunya

- Diputació de Barcelona

- Endesa

- FOBSIC

- Fundació AGBAR

- Garrigues

- Institut Català de les Indústries Culturals

- Mediapro

- Microsoft

- Sanofi Aventis

- ATM, FGC y TMB

The contents of this publication reflect the conclusions and findings of the individual authors, and not the opinions of the Center's sponsors. 


\title{
OWNERSHIP STRUCTURE AND COMPETITIVE BEHAVIOR
}

\author{
BRIAN T. MCCANN \\ Lecturer - Strategic Management \\ Vanderbilt University \\ Owen Graduate School of Management \\ $40121^{\text {st }}$ Avenue South \\ Nashville, TN 37203 \\ Tel: (615) 343-7702 \\ Fax: (615) 343-7177 \\ e-mail: brian.mccann@owen.vanderbilt.edu
}

\section{GOVERT VROOM}

Assistant Professor of Strategic Management

University of Navarra

IESE Business School

Avenida Pearson, 21

08034 Barcelona, Spain

Tel: +34.932534200

Fax: +34.932534343

e-mail:vroom@iese.edu

Version: September 1, 2010 


\title{
OWNERSHIP STRUCTURE AND COMPETITIVE BEHAVIOR
}

\begin{abstract}
While ownership structure has been recognized as an important determinant of firm behavior at the corporate level, its influence on competitive actions has received insufficient attention. To address this gap, we contrast the case of management-controlled and ownercontrolled firms and discuss how the incentives of managers and owners to maximize economic returns may vary across these different ownership structures, leading to heterogeneity in firm competitive behaviors. Our empirical analyses indicate that the relationship of entry, exit, and pricing behaviors to market conditions differs across these two ownership structures.
\end{abstract}




\section{INTRODUCTION}

Studying heterogeneity in firm competitive behaviors, such as entry, exit, price rivalry and other types of competitive actions is a central topic in competitive strategy research. Recent work has prominently recognized that differences in firm characteristics are important determinants of variance in competitive actions. For example, firm founding conditions are important determinants of exit rates (Geroski, Mata, and Portugal, 2010) as is the variety of product lines offered (Dowell, 2006). Entry behaviors differ based on firm capabilities (Lee, 2008) and resource levels (Kalnins and Chung, 2004). Pricing behaviors are affected by the age (Simon, 2005) and the experience level of the firm (McCann and Vroom, 2010). Firm differences are also a central concern in the competitive dynamics literature (e.g., Chen, 1996; Smith, Ferrier, and Ndofor, 2001), which investigates how differences in firms' awareness, motivation, and ability affect their propensity to launch and react to competitive actions.

Despite the progress that has been made in understanding how differences in firm characteristics influence competitive behaviors, the prior literature has been relatively silent about the potential role of heterogeneity in firm ownership structure, where ownership structure is defined as "the relative amounts of ownership claims held by insiders (management) and outsiders (investors with no direct role in the management of the firm)" (Jensen and Meckling, 1976: 305). This limited attention is troubling given that scholars stretching back to Adam Smith (1776) and Berle and Means (1932) have noted that ownership structure can exert a powerful effect on firm decisions. The effect of the split between ownership and control is of central interest to agency theory, and a good deal of research in this area highlights the importance of ownership structure in a variety of corporate-level firm decisions, such as corporate R\&D spending (e.g., Baysinger, Kosnik, and Turk, 1991), diversification (e.g., Denis, Denis, and Sarin, 1997; Goranova, 
Alessandri, Brandes, and Dharwadkar, 2007; Shleifer and Vishny, 1991) and risky investments (e.g., Sanders and Hambrick, 2007; Wright, Ferris, Sarin and Awasthi, 1996; Wright, Kroll, Lado, and Van Ness, 2002). Despite the utility of agency theory in illuminating the influence of ownership structure on these types of firm decisions, the theory has not been broadly applied to examine competitive behaviors. This paper addresses this important gap in the literature by investigating the role of ownership structure in influencing competitive behavior.

Consistent with the prior literature in competitive strategy, we start from the assumption that firms in general attempt to make economically rational decisions that maximize their payoffs through their competitive behaviors. We expect on average that they will be more likely to enter when markets are economically attractive; they will be more likely to exit when recent performance is poor; and, they will alter their prices as market conditions change. Agency theory, however, suggests that the ownership structure of the firm may moderate these relationships due to variance in the objectives of owners and managers across different ownership structures. Our primary research question, then, is whether variance in ownership structure influences competitive behaviors. Specifically, does the relationship of entry, exit, and pricing behaviors to market conditions differ across owner-controlled and management-controlled firms?

While we argue that agency theory provides support for the view that ownership structure will moderate these relationships, our review of the literature suggests that the direction of this moderating influence is ex ante indeterminate. Much of the prior agency literature focuses on the misalignment of interests between owners and managers in the case of separation of ownership and control, leading to a potential failure of management-controlled firms to take advantage of profitable opportunities or the propensity to engage in activities that reduce the value of the firm. In addition to this perspective, we also highlight the ideas of several seminal agency scholars who 
consider how the objectives of owner-controlled firms might vary from profit maximization. Building on these insights from the agency literature, we argue that ownership structures relates to the objectives of both managers and owners, and, therefore, it is not clear whether ownercontrolled or management-controlled firms' competitive behaviors will be more responsive to market conditions. As such, we elect to offer competing hypotheses and allow our empirical tests to address this indeterminacy.

This study contributes to the literature first by addressing a troublesome gap in the current literature on the determinants of competitive behavior. We recognize and investigate ownership structure as a potentially important determinant of competitive behavior. Our work responds to the call of agency theory scholars such as Daily, Dalton, and Rajagopalan (2003: 153) who note, "The differing objective functions attendant on various owner categories must be accounted for in any examination of the nature of the relationship between ownership structure and firm processes and outcomes." We find evidence suggesting that the responsiveness of entry, exit, and pricing decisions does vary systematically based on ownership structure. Second, we also extend the application of agency theory to a new context. The explanatory power and appropriate boundaries of agency theory continue to be subjects of debate in the management literature (e.g., Amihud and Lev, 1999; Denis, Denis, and Sarin, 1999; Lane, Cannella, and Lubatkin, 1998, 1999). In this respect, our approach is similar to recent work by Reuer and Ragozzino (2006) who extend agency theory to examine the question of the composition of firms' alliance portfolios. While agency theory has mainly been applied to corporate-level decisions, its logic should apply to competitive level decisions as well. Finally, our theorizing and empirical analysis further contributes to the strategy literature by suggesting that it might be useful to investigate how owner and manager interests that depart from profit maximization affect the competitive behavior of firms. 
The remainder of the paper proceeds as follows. We begin by developing a set of baseline hypotheses about the relationship between economic signals and entry, exit, and pricing behaviors for firms in general. ${ }^{1}$ We then offer a brief review of agency theory and its arguments for why these relationships might be weaker in management-controlled firms. Next, we draw from the early work of several prominent agency theory scholars and a number of related literature streams to explain why these relationships might be weaker in owner-controlled firms. After describing the data set, measurement issues, and estimation details, we review our empirical results. The final sections discuss and conclude.

\section{THEORY AND HYPOTHESIS DEVELOPMENT}

\section{The Baseline Case}

Firm-level competitive actions are a central concern to competitive strategy (e.g., Porter, 1980; Chen and Miller, 1994; Gimeno, 1999; Smith, Ferrier, and Ndofor, 2001). Competitive behaviors represent actions undertaken by the firm to enhance its relative competitive position, and they include, among others, market entry and exit, signaling behaviors, pricing decisions, marketing actions, new product introductions, and capacity investments. We concentrate on three types of competitive behaviors that have received significant attention in the literature: entry (e.g., McDougall and Robinson, 1990; Baum and Korn, 1996, Kalnins and Chung, 2004), exit (e.g., Barnett, 1993; Baum and Korn, 1996; Boeker, Goodstein and Murmann, 1997), and pricing (e.g., Evans and Kessides, 1994; Gimeno, 1999; Vroom and Gimeno, 2007). Prior to discussing these specific competitive behaviors, we offer two clarifications.

First, consistent with the mainstream of competitive strategy literature, we start from the assumption that firms attempt to make economically rational decisions that maximize their payoffs

\footnotetext{
${ }^{1}$ These hypotheses are not offered for their theoretical originality but rather to establish a foundation upon which to build the arguments regarding the moderating role of ownership structure.
} 
through their competitive behaviors. For example, Porter (1980: 34) describes competitive strategy as taking offensive or defensive actions to "yield a superior return on investment for the firm." Smith, Ferrier, and Ndofor (2001: 315) assume that firms act creatively to "enhance or improve profits, competitive advantage, and industry position.” This baseline assumption implies that firms' competitive behaviors will be responsive to the market conditions under which they operate. We realize that while this responsiveness is expected to hold for firms on average, it may not necessarily hold for each individual firm in all cases. For example, there might be strategic reasons, such as multimarket competition, why individual firm behaviors may at times appear to be unresponsive to market conditions. In spite of the potential for such second-order effects, we expect that competitive behaviors on average will generally be related to market conditions. ${ }^{2}$

Second, because the objectives of firm decision makers are typically not measurable, we infer those objectives via the actions taken by the firm. This approach is comparable to revealed preference approaches utilized in discrete choice models of consumer behavior. Similar to individuals in the consumer choice literature, firms' competitive behaviors are assumed to be driven by underlying objectives. Given that these objectives are largely unobservable, one of the virtues of this paper is a rich empirical context that allows us to observe a variety of behavioral consequences of unobservable objectives.

We first consider entry. In the traditional economic perspective, entry is expected to occur when incumbent firms are earning above-normal returns. That is, firms evaluate the attractiveness of entering a particular market based on the likelihood of earning abnormal profits. A firm will enter a market when the expected discounted value of future profits exceeds entry costs. While the speed of entry in response to profitable opportunities has been described as "fairly slow", the

\footnotetext{
${ }^{2}$ Our empirical estimations will also include a number of controls designed to address other strategic motives that might influence competitive behaviors.
} 
weight of empirical evidence does indicate an increasing positive relationship between expected profitability and entry (Geroski, 1995: 428). Thus, as a first baseline hypothesis we expect that firms will be more likely to enter when market conditions are more attractive.

Hypothesis 1: The economic attractiveness of a market is positively related to the likelihood of entry into that market.

We also consider the relationship between economic performance and the likelihood of exit. Exit is also a very common part of the empirical landscape of business (Geroski, 1995). As in the case of entry, we expect that firms will evaluate the net present value of continuing in business and that these estimates are informed by their recent performance. They will be more likely to exit when prior performance is poor and more likely to continue when performance is strong.

Hypothesis 2: Prior performance is negatively related to exit.

Finally, we consider prices. In the economic view of competition within markets, prices and quantities sold are outcomes of the interplay of supply and demand. Holding supply constant, as demand increases, firms have the ability to charge higher prices. As demand conditions weaken, prices fall. We therefore expect that firms' prices will be related to the economic attractiveness of the local market.

Hypothesis 3: The economic attractiveness of a market is positively related to firm price.

\section{The Influence of Ownership Structure}

We turn now to our comparison of owner-controlled and management-controlled firms, the focus of our paper. Our interest is in understanding how ownership structure affects the incentives and objectives of managers and owners, which in turn affect the competitive behaviors adopted by the firm. We acknowledge that other factors, such as resources and capabilities, might also be 
correlated with ownership structure, an issue we will return to in more detail later in the discussion of our results. In examining the moderating influence of ownership structure, we have elected to present competing hypotheses for two reasons. First, compelling arguments can be made for both directions of the moderating influence as we detail below. Second, it has been argued that the use of competing hypotheses is an under-utilized approach that is particularly appropriate when investigating new research questions (Pleggenkuhle-Miles and Peng, 2008), and the approach has demonstrated its utility in a variety of strategy applications (e.g., Kochhar and David, 1996; Poppo and Zenger, 1998; Goerzen, 2007; Kacperczyk, 2009; Short, McKelvie, Ketchen, and Chandler, 2009).

Management-Controlled Firms. Jensen and Meckling (1976) define the agency relationship as a contract under which one party (the principal) engages another party (the agent) to perform some service on the principal's behalf. In the corporate context, owners, who are assumed to have a goal of profit maximization for the firm, hire managers to run the daily operations of the firm. In contrast to the profit-maximization desires of the owners, managers are assumed to be interested in maximizing their own individual utility rather than firm profitability. When managers do not own significant shares in the firm, their wealth does not vary directly with company performance as Jensen and Murphy (1990) note. ${ }^{3}$ Thus, the ownership structure of the modern corporation, namely the separation of ownership and control, results in the divergence of interests between owners and managers. Scholars as early as Smith (1776: 700) have suggested that "negligence and profusion, therefore, must always prevail" in management-controlled companies because it cannot be expected that those who manage others' money will watch over it with the same "anxious vigilance" as they would watch over their own. In the absence of

\footnotetext{
${ }^{3}$ When managers are also owners, they are assumed to be more likely to act in shareholders' interests because they have similar incentives, the so-called “alignment” view (Dalton, Daily, Certo and Roengpitya, 2003).
} 
alignment between ownership and control, managers behave opportunistically and tend to appropriate perquisites out of the firm's resources for their own consumption (see Dalton, Hitt, Certo, and Dalton, 2007, among others for an overview). Berle and Means (1932: 141) summarize this view, "Have we any justification for assuming that those in control of the modern corporation will also choose to operate it in the interests of the owners?”

Evidence for the consequences of divergent interests between managers and owners has been developed mainly through work examining corporate-level decisions. For example, both Amihud and Lev (1981) and Denis, Denis, and Sarin (1997) noted that diversification of the firm can be viewed as perquisite consumption by managers because it can reduce employment risk and lead to larger salaries. These studies found that firms with lower levels of overlap between management and ownership tended to engage in more diversification. Similarly, Kroll, Wright, Toombs, and Leavell (1997) examined returns from acquisitions in management-controlled firms over the 1982-1991 time period and noted that acquisition announcements generated negative returns for stockholders of these firms. Chen and Steiner (1999) explored the relationship between the lack of managerial ownership and firm risk in a sample of large firms listed on the New York Stock Exchange, finding that management-controlled firms (low levels of overlap between management and ownership) are less willing to undertake risk.

In sum, agency theory predicts that as the amount of ownership by managers decreases, the lower the likelihood that the firm will be operated in congruence with the profit-seeking objectives of the external owners. Rather than being purely motivated by maximizing firm profitability, entry and exit decisions may be influenced by personal objectives such as the desire to increase the size of the firm to reduce employment risk and grow pay and influence. Moreover, given market uncertainty, the limits on the span of attention of managers (Simon, 1947; Ocasio, 1997), and the 
costs associated with monitoring market signals and responding appropriately, the pricing decisions of utility-motivated managers will also be less responsive to market signals. Overall, this perspective would anticipate that the association between market conditions and entry, exit, and pricing behaviors of the firm would be weaker for management-controlled firms when compared to owner-controlled firms.

Hypothesis 1a: The positive relationship between the economic attractiveness of a market and likelihood of entry will be weaker for management-controlled establishments than for owner-controlled establishments.

Hypothesis 2a: The negative relationship between prior performance and likelihood of exit will be weaker for management-controlled establishments than for owner-controlled establishments.

Hypothesis 3a: The positive relationship between the economic attractiveness of a market and firm prices will be weaker for management-controlled establishments than for ownercontrolled establishments.

Much of prior agency theory work concentrates on difference in managerial objectives across different ownership structures. As shown in Figure 1, the role of ownership structure in influencing firm behavior flows through differences in managerial incentives, which result in differences in objectives at the firm level. What has garnered less attention in the recent agency theory literature, however, is the lower pathway of Figure 1. Variance in ownership structure might also be associated with differences in the nature of owner objectives, leading to differences in firm behavior. As we discuss in detail below, the consideration of owner objectives in ownercontrolled firms suggests that the relationship between market conditions and competitive behaviors might be stronger for management-controlled firms relative to owner-controlled firms. 


\section{Insert Figure 1 about here}

Owner-Controlled Firms. The owner-controlled firm, by definition, has no agency problems; however, the lack of agency problems does not necessarily imply that the firm will be a pure profit-seeking entity. Prior literature provides ample support for the assertion that ownermanagers may not have pure profit-maximizing objectives. Several seminal agency thinkers clearly adopted this perspective. For example, Jensen and Meckling (1976: 312) note that an owner-manager's interests involve "not only the benefits he derives from pecuniary returns but also the utility generated by various non-pecuniary aspects of his entrepreneurial activities.” These dual objectives exist because owner-managers may utilize the firm for both consumption and production. Owner-managers will consume within the firm when the consumption possibilities offered there are not available elsewhere (e.g., utility gained from work autonomy or leading an organization) or when the cost of the utility received is lower than if consumption took place in the household (e.g., if tax policy allows certain expenses to be deducted from business but not personal income). Firms can provide their owner-managers with "nonpecuniary income associated with the provision of general leadership and with the ability to deploy resources to suit one’s personal preferences” (Demsetz and Lehn, 1985: 1161-1162). Thus, Demsetz (1983: 382383) observed, "It is clearly an error to suppose that a firm managed by its only owner comes closest to the profit-maximizing firm postulated in the model firm of economic theory.”

The idea that managers of firms with high levels of inside ownership may be motivated by more than just economic returns is supported by a number of related literature streams. Given the high degree of owner management in start-up firms, the entrepreneurship literature is a stream of research that should be particularly relevant to the issue of the goals of owner-managers. Much of the empirical evidence regarding the choice to engage in entrepreneurial activities reflects the 
importance of nonpecuniary motives. First, studies of both prospective and current business owners indicate that businesses are considered (Amit, MacCrimmon, and Zietsma, 2001; Gatewood, Shaver, and Gartner, 1995; Sine and Lee, 2009) and sustained (Gimeno, Folta, Cooper, and Woo, 1997) for both financial and non-financial reasons. Second, comparisons of selfemployed and organizationally employed individuals also support the non-financial rewards of working for oneself (Benz and Frey, 2008; Hundley, 2001). These findings are consistent with earlier work by Aronson (1991) and Hamilton (2000) indicating that the majority of self-employed workers in the United States do not switch to paid employment despite greater income-earning opportunities there. Finally, studies of the economic returns to entrepreneurial activities beyond just self-employment generally indicate that the economic returns are insufficient to adequately compensate owners, leading to a suggestion that nonpecuniary returns make up the difference (e.g., Hamilton, 2000; Moskowitz and Vissing-Jorgensen 2002).

The family business literature also supports the importance of non-financial motivations to inside owners. Schulze, Lubatkin, Dino, and Buchholtz (2001), for example, argue that altruistic tendencies guide many of the decisions within family-run firms. Gomez-Mejia, Haynes, NunezNickel, Jacobsen, and Moyano-Fuents (2007: 106) similarly argue that family firms’ motivations include a desire to attain socioemotional wealth, or "non-financial aspects of the firm that meet the family's affective needs, such as identity, the ability to exercise family influence, and the perpetuation of the family dynasty.”

In summary, owner-managers, who wish to maximize their own utility, may take actions that are inconsistent with profit maximization if those actions serve to increase their individual utility. For example, owner-controlled firms' entry decisions may be less attentive to market signals if those entry decisions generate psychic enjoyment from opening a business near friends 
and family (Dahl and Sorenson, 2009), in the owner-manager's hometown, or in a particularly physically attractive location. Similarly, their exit decisions may be less responsive to performance indicators because of potential non-financial costs such as loss of reputation or imposing unemployment on family or friends. The importance of such psychic income is consistent with the work of Gimeno, Folta, Cooper, and Woo (1997) who found a negative association between psychic income and propensity to exit in a sample of small business owners. Finally, owner-managers' interest in the psychic income aspects of business will restrict the amount of their limited attention span that is devoted to monitoring market signals and responding with changes in pricing practices.

It is not that these owner-managers do not operate the firm in the "interests of owners" as concerned Berle and Means (1932). Rather, it is that the interests of inside owners are not restricted simply to profits. Thus, in the case of the owner-controlled firm, both the owner and manager (who is the same person) will have an objective to maximize utility, which may include both financial and non-financial components. Because we are aware of no ex ante reason to rule out the possibility that this tension between pecuniary and non-pecuniary objectives in ownercontrolled firms outweighs the tension between owner profit and manager utility objectives in management-controlled firms, we offer the following competing hypotheses.

Hypothesis 1b: The positive relationship between the economic attractiveness of a market and likelihood of entry will be weaker for owner-controlled establishments than for management-controlled establishments.

Hypothesis 2b: The negative relationship between prior performance and likelihood of exit will be weaker for owner-controlled establishments than for management-controlled establishments. 
Hypothesis 3b: The positive relationship between the economic attractiveness of a market and firm prices will be weaker for owner-controlled establishments than for managementcontrolled establishments.

\section{METHODS}

\section{Sample}

Investigation of our research questions requires an empirical setting that includes observation of the exit, entry, and pricing behavior of both owner-controlled and managementcontrolled firms along with measures of market attractiveness. The hotel industry provides a particularly appropriate setting because it consists of a wide range of firms from owner-controlled hotels to individual units of management-controlled corporations. Local competition characterizes this industry, as hotels compete with others in the same geographic area but not with hotels in other parts of the state or country (Baum and Mezias, 1992). We draw our sample from the hotel industry in the state of Texas over 34 quarters covering the years 1997 through mid-2005. A mix of independent and chain hotels comprised the sample; the hotel chains operate branded units both through franchise relationships and by company ownership of individual units.

Two primary sources provided the data for our analyses. The first is a publicly available tax file from the State of Texas Comptroller's Office, which provides quarterly reporting of the state’s Hotel Occupancy Tax along with the hotel name, hotel location, owner name/address, hotel capacity, and quarterly revenues. The second data source is a private database from Source Strategy, Inc., a leading hotel consultant that maintains data on Texas hotels from 1976 through the present. This database included the same hotels and also reports quarterly. In addition to the hotel name, their data also included the average quarterly occupancy rate, price, and revenue per 
available room for each hotel. ${ }^{4}$ The first database has been used among others by Chung and Kalnins (2001) and Vroom and Gimeno (2007) while the second database has been used in previous studies such as Conlin and Kadiyali (2006) and Vroom and Gimeno (2007). To focus on hotels and motels as opposed to other types of lodging options that are included in the data set (such as bed and breakfasts and recreational vehicle parks), independent hotels with average room capacities under ten were dropped from the data set.

We utilized the zip code as the definition of the boundaries of an establishment's local market. Although some of the prior literature has used broader county/city-level definitions (e.g., Conlin and Kadiyali, 2006), we believe that narrowing to the zip code level better approximates the choice set consumers review when selecting a hotel. This market definition is consistent with previous studies of the Texas hotel industry (Chung and Kalnins, 2001; Kalnins and Chung, 2004; Vroom and Gimeno, 2007; McCann and Vroom, 2010). During the eight and one-half years included in the data, over 4,000 hotels operated across more than 850 local Texas markets, and the number of hotels grew by 3.3 percent annually.

\section{Dependent Variables and Modeling Approach}

Each of our hypotheses required a different dependent variable and modeling approach as described in more detail below.

Entry. We utilized conditional logit to investigate differences in the entry behavior of owner-controlled and management-controlled establishments (McFadden, 1974). Conditional logit is suitable for location choice decisions among a large set of geographic options (e.g., Head, Ries, and Swenson, 1995; Shaver and Flyer, 2000; Kalnins and Chung, 2004), and it is appropriate for modeling how a broad set of covariates influences the choice of a particular location from a

\footnotetext{
4 The average room price (average daily rate or ADR), the occupancy rate, and the average revenue per available room (RevPAR) are the three most commonly used performance indicators in the hotel industry. The relationship between these three measures is as follows: revenue per available room = occupancy rate $*$ average room price.
} 
number of alternatives. We derived our dependent variable of interest, entry, from a focal hotel's first appearance in the database, and we considered a variety of choice sets.

Exit. Our dependent variable for the exit models was a binary dependent variable coded "1" if the hotel exited during a particular quarter and " 0 " otherwise. To avoid potential bias that might result from censored cases, we analyzed the hazard of exit using both semiparametric and parametric survival models with time-varying covariates. To accommodate time variation in the covariates, we divided the data into quarterly spells, resulting in 105,037 establishment-quarter observations in the total sample.

Pricing. The dependent variable in these analyses was the logged average daily price of an individual hotel room. To control for potential unobserved sources of heterogeneity that might impact prices, we utilized hotel-level fixed effects regression to model prices. The sample includes 108,153 establishment-quarter observations. ${ }^{5}$

\section{Independent and Control Variables}

Our measure of ownership structure is a dummy variable indicating whether a hotel was owner-controlled or management-controlled. In the hotel industry, individual establishments are either independent or affiliated with a particular chain. Chain-affiliated establishments may be owned by the chain (company-owned) or by franchisees. We defined all company-owned units to be management-controlled. ${ }^{6}$ To determine the ownership type of franchised and independent units, we defined a hotel to be owner-controlled if its owner's zip code as reported in the State of Texas records was the same as the zip code of the hotel. Typically owners who also manage their hotel

\footnotetext{
${ }^{5}$ The exit sample is slightly smaller than the pricing sample due to deletion of observations with missing data on prior firm occupancy.

${ }^{6}$ Some hotel chains (e.g., Hyatt Hotels) feature partial separation of ownership and control in that some members of the founding family maintain ownership and managerial positions. Owners also include family members with no managerial roles and outside investors. We elected to include this type of chain in the management-controlled category for two reasons. First, our theoretical development regarding owner-controlled firms concentrates on the case of full overlap between management and control. Second, these chains include professional management throughout the organization in addition to the family managers who maintain ownership positions.
} 
live relatively close to their establishment. Living nearby (e.g., in the same zip code) allows the owner to closely monitor and supervise their property, even if they have professional staff assisting them in the management of the hotel. In contrast, close supervision would not be feasible when living farther away and would require the use of control and decision-making systems similar to those of management-controlled organizations. Of the 3,289 hotels operating at the mid-point of the data set, 1,799 (55 percent) were owner-controlled and 1,490 (45 percent) were management-controlled. We also considered an alternative definition in which we defined hotels to be owner-controlled if the hotel owner lived within the state and owned no more than a single hotel. This broader definition of owner-management resulted in 2,240 hotels (68 percent) being classified as owner-controlled.

Entry models. Our measure of the attractiveness of a particular market is the average occupancy rate (the percentage of occupied rooms) across all hotels in a particular zip code. Mean occupancy rates reflect the strength of local market demand conditions. When demand is high relative to supply, market occupancy, market prices, and market profitability all tend to increase, suggesting that mean occupancy is a good indicator for the economic attractiveness of the market.

To control for differences in access to resources and capabilities across owner-controlled and management-controlled establishments, we calculated the total capacity (number of rooms) owned by each owner across all of its establishments. We expect that establishments that are part of larger organizations may have access to greater financial resources and that larger organizations are more willing and able to invest in the development and transfer of managerial capabilities throughout the organization. We also controlled for other factors that may impact entry to markets, including a measure of market concentration, calculated as the sum of the squared market shares of all hotels in the zip code, and the logarithm of market capacity (the total number of rooms of all 
hotels in the zip code) to control for variations in supply conditions. Market mean occupancy and the other time variant market-level controls were lagged four periods (one year) to reflect the fact that entry decisions are made well in advance of the actual observation of the opening of the hotel. We also controlled for whether other hotels of the same chain are located within the market because brands often avoid locating multiple hotels in the same market. We also measured the degree of multimarket contact available to the entrant in each potential market, as the multi-market literature (e.g., Gimeno, 1999) suggests that rival firms may seek out contact across multiple markets to establish mutual forbearance. ${ }^{7}$

Other market-level controls include a dummy variable indicating whether the market was in a rural location and measures of the level of economic activity within the zip code, drawn from the 2002 Zip Code Business Patterns available from the U.S. Census Bureau (number of retail and gas establishments in the zip code). We also controlled for the income level, population, and number of housing units within the zip code using data drawn from the 2000 U.S. Census. The Census measures were all log-transformed.

Exit models. To capture responsiveness to recent performance, our primary independent variable is the establishment's occupancy level in the prior quarter. The exit models also include the same set of control variables as the entry models, although the market-level measures were lagged one period instead of four due to the fact that exit decisions are likely made more closely in time to the observation of exit in the data set. In addition, we added firm-level controls of the segment in which the hotels operated to capture any differences in exit behavior across hotels of different size and quality. We utilized the Smith Travel Research (STR) Chain Scales to classify

\footnotetext{
${ }^{7}$ We also considered the inclusion of a measure of distance to the owner's headquarters as owners may prefer to locate new establishments closer to headquarters to facilitate monitoring (Kalnins and Lafontaine, 2004). We elected not to include this measure in the reported results because of the preponderance of single-owner entries in our data for whom distance to headquarters for the first hotel is not a meaningful measure. In unreported models, however, the variable had the expected negative significant effect and our substantive results did not change.
} 
hotels into four segments (Economy, Midscale, Upscale, and Luxury). Independent hotels (not chain-affiliated) were classified into these segments based on their average room price over the life of the data set.

Pricing models. In addition to hotel-level fixed establishment effects that control for unobserved sources of heterogeneity, these regressions included fixed segment and period effects. Market-level controls included market capacity and concentration as described above. These measures were lagged one period as was the measure of market occupancy. We also included controls for whether the hotel was a franchised or company-owned unit (with independent being the excluded category). ${ }^{8}$

\section{RESULTS}

We begin with some descriptive statistics comparing management-controlled and ownercontrolled establishments. In general, Table 1 indicates that the management-controlled hotels tend to be larger, and they also exhibit higher occupancy levels, prices, and quality levels. Their owners tend to own a number of additional hotels as well; on average, a management-controlled establishment shares common ownership with 15 other establishments. Finally, they exhibit a mix of ownership forms, including company-owned, franchised, and independent units. The ownercontrolled establishments are a mix of both franchised and independent units, and the average number of establishments owned is slightly larger than one. At the market level, managementcontrolled units tend to be located in stronger markets; their markets have higher capacity, occupancy, prices, and quality levels, but slightly lower concentration. The average population, income, and number of competing establishments are also higher.

Insert Table 1 about here-

\footnotetext{
${ }^{8}$ We excluded any time-invariant measures from the fixed effects regressions because these time-invariant effects are captured by the fixed establishment effects. Segment and franchise / company-owned controls are included because some hotels switch segments and ownership structure over the course of the data set.
} 
We next review some descriptive statistics related to our choice of mean market occupancy and prior firm occupancy as measures of economic attractiveness. First, we compared prices and entry activity across markets above and below the median market occupancy level. The average daily price of a hotel room in more attractive markets (\$59.25) is over 19 percent higher than the average price in less attractive markets (\$49.52), and attractive markets draw nearly twice as many entrants (685 vs. 396). These descriptive statistics support mean market occupancy as an indicator of market attractiveness, and the results are consistent with our expectations of the direct effects of this measure. Second, a comparison of average prior firm occupancy rates for firms who exited (40.05\%) versus those who survived (54.4\%) also supports the choice of firm occupancy for the exit regressions.

\section{Entry}

Table 2 presents the results of the conditional logit entry analyses. We provide the results from choice sets of the nearest 250 and 200 markets; the results, however, are robust to a variety of choice sets, including ones as small as the nearest ten markets and on choice sets based on a variety of radial distances (10, 20, and 50 miles). We also confirmed that a Hausman test fails to reject the conditional logit model's assumption of Independence of Irrelevant Alternatives $(\mathrm{p}=0.19)$. The positive coefficient on Market Occupancy in Model 1 supports Hypothesis 1, the baseline prediction that entry behaviors are influenced by signals of market attractiveness. Firms are more likely to enter markets with higher levels of occupancy. Specifically, the coefficient of 0.020 indicates that a one percentage point increase in market occupancy is associated with a two percent increase in the odds that a market will be chosen for entry. 
We now turn to the potential moderating influence of ownership structure. Model 2 introduces the interaction of Owner-Controlled * Market Occupancy. ${ }^{9}$ The negative interaction effect supports Hypothesis $1 \mathrm{~b}$ and its prediction that the positive relationship between market occupancy and probability of entry would be weaker for owner-controlled firms, and does not support Hypothesis 1a. Panel A of Figure 2 presents this result graphically, showing that increases in market occupancy levels have a more positive relationship to log odds of entry for management-controlled firms. To ensure that this relationship was not merely proxying for a difference in the relationship across firms of different resource levels, Model 3 introduces an interaction with the owner capacity variable. The coefficient on this variable is positive, but not significant. While the Owner-Controlled * Market Occupancy interaction is slightly reduced, it remains negative and significant. The results are quite similar in Models $4-6$, which are based on the smaller choice set. Overall, the models support a conclusion that the relationship between entry behaviors and market attractiveness is weaker for owner-controlled firms.

These results were robust to a number of alternative specifications, including our alternative definition of owner-manager. We also investigated different lags of market occupancy, including an average going back an additional year. In addition, we examined models that defined markets based on segments within zip codes. In these models, we replaced the market occupancy, concentration, and capacity measures (aggregated at the zip code level) with measures aggregated at the segment level of the entrant (Economy, Midscale, Upscale, or Luxury) within each zip code. The substantive results of the analysis were robust to all of these alternative specifications and provided broad support for Hypothesis 1b. Overall, the relationship between market attractiveness and entry is stronger for management-controlled firms.

\footnotetext{
${ }^{9}$ We do not include the main effect of Owner-Controlled in the specification. The effect is inestimable in the conditional logit model because the variable does not vary within choices.
} 
Insert Table 2 about here-

Insert Figure 2 about here-

\section{Exit}

Table 3 provides the results of our exit analyses, which include both Cox proportional hazards (semiparametric) and Weibull (parametric) survival models. Because we have multiple observations per zip code, the models utilized robust standard errors, clustered to adjust for intrazip correlation. The negative coefficient on Prior Unit Occupancy in Model 7 supports our baseline prediction (Hypothesis 2) that the hazard of exit decreases at higher levels of establishment occupancy. The coefficient of -0.062 indicates that a one percentage point increase in firm occupancy is associated with a six percent decrease in the hazard of exit. ${ }^{10}$ The effect is quite similar in the Weibull model results (Model 10).

Models 8 and 11 add the interaction of Owner-Controlled * Prior Unit Occupancy. The significant positive interactions imply that the negative main effect of prior unit occupancy is weaker (less negative) for owner-controlled establishments, supporting Hypothesis 2b and not Hypothesis 2a. The difference in the relationships between prior unit occupancy and likelihood of exit is shown in Panel B of Figure 2. While both types of firms are more likely to exit as unit occupancy decreases, this relationship is weaker for the owner-controlled establishments. The result is unchanged even controlling for the interaction with the resource level of the owner (total capacity) as shown in Models 9 and 12.

Our exit results were robust to our alternative definition of owner-manager and to a variety of alternative specifications. We examined binary logit, random effects logit, and complementary log-log models of the exit decision, all of which produced similar results. The results were also

\footnotetext{
${ }^{10}$ The baseline hazard is multiplicatively increased by $\exp (-0.062)$ or 0.94 , which represents an approximate six percent decrease.
} 
similar using a measure of average firm occupancy over the prior four quarters as well as using a market occupancy measure (average occupancy level in the zip code) rather than a firm-level measure.

Insert Tables 3 and 4 about here-

\section{Pricing}

Table 4 presents the results of our analysis for the pricing behavior of hotels using a fixed effects regression specification with robust standard errors, clustered to adjust for intrafirm correlation. Results of a Hausman test indicated that the fixed effects specification was preferred to a random effects specification, although the substantive results were unchanged across the specifications. The positive coefficient on Market Occupancy in Model 13 indicates that hotels in markets with higher prior quarter occupancy levels have higher prices as predicted by Hypothesis 3. The coefficient of 0.0021 in Model 13 indicates that a one standard deviation increase in Market Occupancy (11.41 percentage points) is associated with prices that are $2.39 \%$ higher. The significant negative coefficient of -0.0007 on the interaction of Owner-Controlled * Market Occupancy in Model 14 indicates that the positive main effect is weaker for owner-controlled establishments, consistent with the prediction of Hypothesis 3b. The Model 14 results indicate that the prices of management-controlled firms are 2.89\% higher when market occupancy levels increase one standard deviation while the prices of owner-controlled firms are $2.07 \%$ higher. This difference of $0.82 \%$ has a meaningful economic impact. For the average hotel in our data set with a capacity of 91 rooms and an occupancy level of 55 percent, increasing price $0.82 \%$ above its average level translates into an annual revenue increase of just under $\$ 10,000$. While both ownercontrolled and management-controlled establishments price higher when demand conditions are more favorable, this relationship is stronger for the management-controlled establishments. These 
results were robust to the alternative definition of owner-manager as well as to the use of segmentbased market measures.

\section{DISCUSSION}

A wealth of research has investigated the link between ownership structure and corporate behaviors as well as the link between ownership structure and performance generally (e.g., Thomsen and Pedersen, 2000; Durand and Vargas, 2003; also see Dalton, Daily, Certo, and Roengpitya, 2003 for a summary and meta-analysis). As a complement to these literature streams, we set out with the purpose of testing whether and how the ownership structure of the firm affects competitive behaviors. Specifically, we investigated whether the relationship of entry, exit, and pricing behaviors to market conditions differed across owner-controlled and managementcontrolled firms. We reviewed theoretical arguments supporting the potential moderating influence of ownership structure while noting the ex ante indeterminacy in the direction of the moderating influence. Recent agency theory work led to a prediction that the relationships would be weaker for management-controlled firms because of the incentive conflict between profitseeking owners and utility-seeking managers. In contrast, insights drawn from several early agency scholars and from work examining the motives of entrepreneurs and family business predicted that the baseline relationships could be weaker for owner-controlled firms who use their businesses to pursue both economic and non-economic returns. Our empirical analyses indicated that the entry, exit, and pricing decisions of owner-controlled establishments are less responsive to economic conditions relative to the decisions of management-controlled establishments.

Our aim in this paper was not to gather evidence to conclude that one of these perspectives was "more correct" than the other. Moreover, we do not interpret our results to be in conflict with predictions based on principal-agent problems. Our perspective is that both types of distortions 
away from the ideal of profit maximization likely play a role in firms. In our context, however, the distortion in owner-controlled firms appears to outweigh the distortion in managementcontrolled firms.

The stronger owner-managed distortion may be associated with unique aspects of our empirical context. The availability of franchising, the limiting of competition to local areas, the relatively low requirements for specialized skills, and the critical importance of location (relative to individual skills) in the hotel industry may all combine to create an environment more conducive to owner-managers who are less profit-focused. More generally, we believe that more munificent environments, industries that are more likely to offer non-pecuniary returns, and industries with low entry barriers might result in a higher level of owner-managed firms that place less emphasis on maximizing profits.

For management-controlled firms, we have assumed that firm owners are interested in profit maximization. This assumption flowed from the fact that diffuse, external owners have no ability to extract utility directly from the operations of the firm. The only source of utility available to them is the stream of monetary rewards flowing from the firm. Whether firm behavior actually reflects this owner goal will likely relate to whether opportunities exist for managers to appropriate value and how agency issues are controlled. We note that a variety of mechanisms are available to reduce agency conflicts, and the growth and prominence of literature concerned with agency problems has led firms to increase their efforts to address these problems. First, Fama and Jensen (1983: 331) note that decision making control can be separated from the locus of utility benefits by separating decision management (initiation and implementation) and control (ratification and monitoring). In the case of hierarchical organization, decision making rights can be assigned to managers other than those who would directly gain from particular 
decisions. For example, if local managers of a geographically diverse organization potentially gain non-pecuniary benefits from certain decisions made at the local level, those decision rights can be assigned to regional or corporate level managers who do not benefit from the local nonpecuniary benefits. Second, incentive pay, use of which is becoming more widespread (Byrd, Parrino and Pritsch, 1998; World at Work, 2008), can be used to align the goals of managers toward profit maximization. Firms who use lower levels of incentive pay can compensate with other agency controls, such as higher monitoring (Beatty and Zajac, 1994). Third, a host of other non-monetary incentives exist that encourage profit-seeking behavior on the part of managers such as the desire to avoid punishment, the quest to advance in intra-company "promotion tournaments" (Lazear and Rosen, 1981), and the need to establish a good reputation in the managerial labor market (Gibbons and Murphy, 1992). To the extent that effective measures are in place to align interests of owners and managers, management-controlled firms are more likely to portray a strong relationship between market conditions and their competitive behavior, compared to ownercontrolled firms.

We invite more research into the relative strength of these distortions away from profit maximizing behavior in other empirical contexts. As a first step, our research indicates that ownership structure is an important source of firm heterogeneity that contributes to differences in competitive behavior. Our comparison of owner-controlled to management-controlled firms is particularly important given the significant role played by firms in which ownership and control are unlikely to be fully separated. The U.S. Census Bureau estimates that there are over 22 million private businesses in the U.S., accounting for 40 to 60 percent of GDP (Scott Morton and Podolny, 2002). Moskowitz and Vissing-Jorgenson (2002) estimate that individuals' investments in private business equal $\$ 5.7$ trillion, only slightly trailing investments in public equity of $\$ 7.3$ trillion. 
Our work shows that agency theory offers a potentially fruitful addition to the study of competitive behavior. While this study will obviously not resolve the debate about the explanatory power and suitable boundaries of agency theory, our results do suggest that concepts drawn from agency theory are useful tools in the investigation of competitive actions. A promising extension of our work would be to examine how other concepts drawn from agency theory, such as incentive pay, board structure, and the like, might also be integrated into the competitive strategy literature. $^{11}$

Finally, our research suggests that it might be useful to consider how investigating distortions away from profit maximization might advance our understanding of firms’ competitive behaviors. Whether firms maximize profits in reality has been the subject of recurring debate, and scholars have offered a variety of objections to the profit maximization assumption. These objections have highlighted ability limitations (e.g., Simon, 1947), organizational obstacles (e.g., Cyert and March, 1963), agency issues (e.g., Jensen and Meckling, 1976), and alternative nonmonetary objectives (e.g., Machlup, 1967) among other reasons why firms may not engage in profit maximizing behaviors. Although the profit maximization assumption has been attacked from a number of directions, it has also been prominently defended, most notably by Friedman (1953) who offered one of the more well-known defenses of the profit-maximization assumption. He argued that firms that did not engage in profit-maximizing behaviors would eventually be selected out of the environment and suggested that this justified the assumption of firms' behaving as if they were seeking rationally to maximize expected returns. Alchian (1950) similarly argued

\footnotetext{
${ }^{11}$ A stream of research in economics referred to as strategic delegation theory touches upon some of these issues. For example, Vickers (1985) argued that managers given an incentive to profit maximize might actually end up generating lower profits than managers without this incentive. See Fershtman and Judd (1987) and Sklivas (1987) for a formal treatment of strategic delegation using game theoretic models.
} 
that profit maximization is not a result of firm decisions but rather a result of an evolutionary process being conducted at an industry-wide level.

While the above literature has debated whether firms in general reach the theoretical ideal of profit maximization, our purpose is to suggest that there is value in considering that different types of firms more closely approach this theoretical ideal than do other firms. Furthermore, the extent to which firms approach the ideal will have predictable effects on the competitive behaviors they adopt. We believe that investigating the effects of varying objectives on competitive actions offers a promising area of future research because the competitive strategy literature from both the industrial organization perspective (e.g., Porter, 1980) and the competitive dynamics approach (e.g., Smith, Ferrier, and Ndofor, 2001) has largely adopted the profit maximization assumption despite the voluminous debate that has featured serious objections to this assumption. Overall, the strategy literature in general might find it useful to more fully investigate variance in objectives to further the quest to understand performance heterogeneity across firms.

Our findings provide some interesting links to other literature streams. A recent series of papers (Lubatkin, Schulze, Ling, and Dino, 2005; Schulze et al., 2001; Schulze, Lubatkin, and Dino, 2002) have questioned how well family firms approximate the theoretical profit-maximizing entity devoid of agency problems. Family firms typically feature partial separation of ownership and control; while a number of the family owners are actively involved in management of the firm, other family members are passive owners who take no part in management. This stream of research has argued that this partial separation results in agency problems that may lead to managerial behaviors inconsistent with profit-maximization objectives. Investigating how this partial separation of ownership and control affects the competitive behaviors of family firms is an interesting area for future research. 
Our findings also relate to research in the competitive dynamics literature. This research stream investigates competitive interactions among firms and posits three implicit drivers of competitive action or response - a firm's awareness of a competitive relationship and/or competitors' initiatives, its motivation or incentive to act or respond, and its capability to act or respond (Chen, 1996; Chen, Su, and Tsai, 2007; Smith, Ferrier, and Ndofor, 2001). Our work relates strongly to the motivation driver with our argument that ownership structure influences the incentives of firm decision makers. A promising extension of this work would be to more fully integrate it with the competitive dynamics literature to examine whether ownership structure affects other factors studied closely in this research stream such as the propensity to initiate and/or respond to competitive actions and the speed at which moves are made.

Although our focus in this paper has been on the comparison of competitive behaviors of owner-controlled and management-controlled firms, an interesting extension of this work would be to examine how the presence of owner-controlled establishments affects the competitive behaviors of management-controlled establishments. Are owner-controlled firms seen as weaker competitors because of their lack of profit-seeking behavior such that management-controlled firms might seek them out as easy prey? How might the lower responsiveness of owner-manager prices to market conditions affect the pricing strategies of management-controlled firms? These are just a few of the questions that might extend this work to provide a richer view of the impact of owner-controlled firms on the nature of competition within a particular industry or market.

\section{Alternative Explanations}

We now consider potential alternative explanations for our findings. First, one might argue that a key difference between owner-controlled and management-controlled firms is their access to resources and capabilities, and this difference might explain the variance in their 
behaviors. We do note that all of our results included a control to proxy for the resources and capabilities available to the firm. Obviously, this control is an imperfect proxy and while our data do not allow us to entirely rule out this alternative explanation, we do not believe that heterogeneity in access to financial resources or managerial capabilities accounts for the differences we observe in competitive behaviors for several reasons. We first consider financial resources. If more economically attractive markets are more expensive to enter and managementcontrolled firms have better access to financial resources, this could also explain the relationship we observe; however, the data do not appear to support this alternative. First, as one rough measure of the cost of entry into different markets, we examined entry patterns into rural and metropolitan markets. If resource differences constrain the entry ability of owner-controlled firms, we would expect to see much lower rates of owner-manager entry into metropolitan markets relative to the entry rates of management-controlled firms into these markets. We found that 86.6 percent of the management-controlled entries were into metropolitan markets while 81.7 percent of the owner-manager entries were into metropolitan markets. While owner-managers do enter more costly metropolitan markets at lower rates, they still enter at very high rates and the difference between the two types of firms is not particularly large. Second, and more importantly, financial resource differences would not provide an alternative explanation for the exit and pricing findings. In particular, if owner-managers are more resource-constrained, we would expect to see their exit decisions be more responsive to the recent performance, not less responsive as we observed.

We also consider differences in managerial capabilities. A concern may be that we observe weaker responsiveness to economic conditions from owner-controlled establishments because they are not sophisticated or knowledgeable enough to understand the correct response. 
Knowledge differences might, for example, be associated with the fact that many of the management-controlled establishments are members of chain organizations, and the experiences of the organization can serve as a source of learning for all members of the chain (Baum and Ingram, 1998). Again, we cannot rule this explanation out with the data we have available; however, we do argue that an alternative explanation relying on differences in knowledge or cognitive abilities is somewhat implausible in our context. We specifically chose obvious measures of economic performance that are available to both owner-controlled and managementcontrolled firms, and we believe it does not take a high level of knowledge or sophistication for any manager to understand that markets with higher occupancy levels provide more attractive economic conditions and that low unit occupancy rates are indicative of a struggling hotel.

Finally, we note that some might argue that management-controlled firms have different time horizons than do owner-controlled firms. Management-controlled firms might be more focused on short-term results due to increased focus on short-term goals such as quarterly earnings in public firms, or even in private firms that closely monitor short-term performance targets. In contrast, owner-controlled firms might be more likely to focus on the longer term, especially if the business is part of a legacy that will eventually be handed down to future generations. This particular consideration might not affect our results for two reasons. First, we can conceive an argument for the opposite perspective. Owner-controlled firms, who may be liquidity constrained, may be forced to focus on the short-term in order to ensure sufficient capital to maintain operations. Moreover, in the absence of a next generation to take over a business, ownermanagers who are looking to retire or otherwise exit from the business are unlikely to take a longterm perspective. Therefore, we do not believe it is clear ex ante which type of firm might be more focused on short-term results. Second, it is unclear how a difference in time horizons might 
account for our findings. If we accept the argument that management-controlled firms are more interested in short-term results, how would this lead them to be more responsive to market conditions? One would expect that being responsive to the economic attractiveness of the firm's market would make sense regardless of a desire to maximize short- or long-term results.

\section{CONCLUSION}

The quest to understand heterogeneity in firm competitive behaviors is a fundamental research topic in competitive strategy research. Although early work in this area assumed that firms were essentially homogenous in their makeup, more recent research has examined how variance in firm characteristics is related to competitive action heterogeneity. We extend this research by considering the role of differences in ownership structure, a firm characteristic that has been demonstrated in other streams of management research to exert a powerful influence on firm actions. Drawing from diverse literature streams, we offered competing hypotheses regarding the moderating influence of ownership structure on the competitive behaviors of owner-controlled and management-controlled firms, and our results demonstrated that the entry, exit, and pricing decisions of management-controlled establishments, in comparison with those of owner-controlled establishments, are more responsive to the underlying economic conditions of the markets in which they operate. These results are consistent with the perspective that management-controlled firms are more likely than owner-controlled firms to be profit-seeking in our empirical context. Our study suggests that the quest to explain heterogeneity in competitive behaviors should consider how differences in ownership structure may influence heterogeneity in owner and manager objectives, which ultimately express themselves through differences in competitive actions. 


\section{REFERENCES}

Alchian A. 1950. Uncertainty, evolution and economic theory, Journal of Political Economy, 58 (3): 211-221.

Amihud Y, Lev B. 1981. Risk reduction as a managerial motive for conglomerate mergers. Bell Journal of Economics, 12 (2): 605-617.

Amihud Y, Lev B. 1999. Does corporate ownership structure affect its strategy towards diversification? Strategic Management Journal, 20 (11): 1063-1069.

Amit R, MacCrimmon KR, Zietsma C. 2001. Does money matter? Wealth attainment as the motive for initiating growth-oriented technology ventures. Journal of Business Venturing, 16 (2), 119-143.

Aronson RL. 1991. Self-employment: A labor market perspective. Ithaca, NY: ILR Press.

Barnett WP. 1993. Strategic deterrence among multipoint competitors. Industrial and Corporate Change, 2 (1): 249-278.

Baum JAC, Ingram P. 1998. Survival-enhancing learning in the Manhattan hotel industryy, 18981980. Management Science, 44 (7): 996-1016.

Baum JAC, Korn HJ. 1996. Competitive dynamics of interfirm rivalry. Academy of Management Journal, 39 (2): 255-291.

Baum JAC, Mezias SJ. 1992. Localized competition and organizational failure in the Manhattan hotel industry, 1898-1990. Administrative Science Quarterly, 37 (4): 580-604.

Baysinger BD, Kosnik RD, Turk TA. 1991. Effects of board and ownership structure on corporate R\&D strategy. Academy of Management Journal, 34 (1): 205-214.

Beatty RB, Zajac EJ. 1994. Managerial incentives, monitoring, and risk bearing: A study of executive compensation, ownership, and board structure in initial public offerings. Administrative Science Quarterly, 39 (2): 313-335.

Benz M, Frey BS. 2008. Being independent is a great thing: Subjective evaluations of selfemployment and hierarchy. Economica, 75 (298): 362-383.

Berle AA, Means GC. 1932. The modern corporation and private property. New York: Macmillan.

Boeker W, Goodstein J, Stephan J, Murmann JP. 1997. Competition in a multimarket environment: The case of market exit. Organization Science, 8 (2): 126-142.

Byrd J, Parrino R, Pritsch G. 1998. Stockholder-manager conflicts and firm value, Financial Analysts Journal, 54 (3): 14-30.

Chen MJ. 1996. Competitor analysis and interfirm rivalry: Toward a theoretical integration. Academy of Management Review. 21 (1): 100-134.

Chen M-J, Miller D. 1994. Competitive attack, retaliation and performance: An expectancyvalence framework. Strategic Management Journal, 15(2): 85-102.

Chen CR, Steiner TL. 1999. Managerial ownership and agency conflicts: A nonlinear simultaneous equation analysis of managerial ownership, risk taking, debt policy, and dividend policy. Financial Review, 34(1): 119-136.

Chen MJ, Su KH, Tsai W. 2007. Competitive tension: The awareness-motivation-capability perspective. Academy of Management Journal, 50 (1): 101-118.

Chung W, Kalnins A. 2001. Agglomeration effects and performance: A test of the Texas lodging 
industry. Strategic Management Journal, 22 (10): 969-988.

Conlin M, Kadiyali V. 2006. Entry-deterring capacity in the Texas lodging industry. Journal of Economics \& Management Strategy, 15 (1): 167-185.

Cyert RM, March JG. 1963. A behavioral theory of the firm. Englewood Cliffs, NJ: Prentice Hall.

Dahl MS, Sorenson O. 2009. The embedded entrepreneur. European Management Review, 6(3): 172-181.

Daily CM, Dalton DR, Rajagopalan N. 2003. Governance through ownership: Centuries of practice, decades of research. Academy of Management Journal, 46 (2): 151-158.

Dalton DR, Daily CM, Certo ST, Roengpitya R. 2003. Meta-analyses of financial performance and equity: Fusion or confusion? Academy of Management Journal, 46(1): 13-26.

Dalton D, Hitt MA, Certo ST, Dalton CM. 2007. The fundamental agency problem and its mitigation. The Academy of Management Annals, 1 (1): 1 - 64.

Demsetz H. 1983. The structure of ownership and the theory of the firm. Journal of Law and Economics, 26 (2): 375-390.

Demsetz H, Lehn K. 1985. The structure of corporate ownership: Causes and consequences. Journal of Political Economy, 93 (6): 1155-1177.

Denis DJ, Denis DK, Sarin A. 1997. Agency problems, equity ownership, and corporate diversification. Journal of Financial Economics, 52 (1): 135-160.

Denis DJ, Denis DK, Sarin A. 1999. Agency theory and the influence of equity ownership structure on corporate diversification strategies. Strategic Management Journal, 20 (11): 1071-1076.

Dowell G. 2006. Product line strategies of new entrants in an established industry: evidence from the US bicycle industry. Strategic Management Journal, 27 (10): 959-979.

Durand R, Vargas V. 2003. Ownership, organization, and private firms' efficient use of resources. Strategic Management Journal, 24 (7): 667-675.

Evans WN, Kessides IN. 1994. Living by the "Golden Rule": multimarket contact in the U.S. airline industry. Quarterly Journal of Economics, 109 (2): 341-366.

Fama EF, Jensen MC. 1983. Agency problems and residual claims. Journal of Law and Economics, 26 (2): 327-349.

Fershtman C, Judd KL. 1987. Equilibrium incentives in oligopoly. American Economic Review, 77 (5): 927-940.

Friedman M. 1953. Essays in positive economics, Chicago: University of Chicago Press.

Gatewood EJ, Shaver KG, Gartner WB. 1995. A longitudinal study of cognitive factors influencing start-up behaviors and success at venture creation. Journal of Business Venturing, 10 (5): 371-391.

Geroski PA. 1995. What do we know about entry? International Journal of Industrial Organization, 13 (4): 421-440.

Geroski PA, Mata J, Portugal P. 2010. Founding conditions and the survival of new firms. Strategic Management Journal, 31 (5): 510-529.

Gibbons R, Murphy KJ. 1992. Optimal incentive contracts in the presence of career concerns: Theory and evidence. Journal of Political Economy, 100(3): 468-505.

Gimeno J. 1999. Reciprocal threats in multimarket rivalry: Staking out 'spheres of influence' in 
the U.S. airline industry. Strategic Management Journal, 20(2): 101-128.

Gimeno J, Folta TB, Cooper AC, Woo CY. 1997. Survival of the fittest? Entrepreneurial human capital and the persistence of underperforming firms. Administrative Science Quarterly, 42(4): 750-783.

Goerzen A. 2007. Alliance networks and firm performance: The impact of repeated partnerships. Strategic Management Journal, 28 (5): 487-509.

Gomez-Mejia LR, Haynes KT, Nunez-Nickel M, Jacobson KJL, Moyano-Fuentes J. 2007. Socioemotional wealth and business risks in family-controlled firms: Evidence from Spanish olive oil mills. Administrative Science Quarterly, 52 (1): 106-137.

Goranova M, Alessandri TM, Brandes P, Dharwadkar R. 2007. Managerial ownership and corporate diversification: a longitudinal view. Strategic Management Journal, 28 (3): 211-225.

Hamilton B. 2000. Does entrepreneurship pay? An empirical analysis of the returns of selfemployment. Journal of Political Economy, 108 (3): 604-631.

Head K, Ries J, Swenson D. 1995. Agglomeration benefits and location choice: Evidence from Japanese manufacturing investments in the United-States. Journal of International Economics, 38(3-4): 223-247.

Hundley G. 2001. Why and when are the self-employed more satisfied with their work? Industrial Relations, 40 (2): 293-316.

Jensen M, Meckling W. 1976. Theory of the firm: managerial behavior, agency costs and ownership structure. Journal of Financial Economics, 3(4): 305-360

Jensen MC, Murphy KJ. 1990. Performance pay and top-management incentives. The Journal of Political Economy, 98 (2): 225-264

Kalnins A, Chung W. 2004. Resource-seeking agglomeration: A study of market entry in the lodging industry. Strategic Management Journal, 25 (7): 689-699.

Kalnins A, Lafontaine F. 2004. Multi-unit ownership in franchising: evidence from the fast-food industry in Texas. RAND Journal of Economics, 35(4): 747-761.

Kacperczyk A. 2009. With greater power comes greater responsibility? Takeover protection and corporate attention to stakeholders. Strategic Management Journal, 30 (3): 261-285.

Kochhar R, David P. 1996. Institutional investors and firm innovation: A test of competing hypotheses. Strategic Management Journal, 17 (1): 73-84.

Kroll M, Wright P, Toombs L, Leavell H. 1997. Form of control: A critical determinant of acquisition performance and CEO rewards. Strategic Management Journal, 18 (2): 85-96.

Lane PJ, Cannella AA, Lubatkin MH. 1998. Agency problems as antecedents to unrelated mergers and diversification: Amihud and Lev reconsidered. Strategic Management Journal, 19 (6): 555-578.

Lane PJ, Cannella AA, Lubatkin MH. 1999. Ownership structure and corporate strategy: one question viewed from two different worlds. Strategic Management Journal, 20 (11): 10771086.

Lazear EP, Rosen S. 1981 Rank-order tournaments as optimal labor contracts. Journal of Political Economy, 89(5): 841-864.

Lee G. 2008. Relevance of organizational capabilities and its dynamics: what to learn from entrants' product portfolios about the determinants of entry timing. Strategic Management Journal, 29 (12): 1257-1280. 
Lubatkin MH, Schulze WS, Ling Y, Dino RN. 2005. The effects of parental altruism on the governance of family-managed firms. Journal of Organizational Behavior, 26 (3): 313-330.

Machlup F. 1967. Theories of the firm: Marginalist, behavioral, managerial. American Economic Review, 57 (1): 1-33.

McCann BT, Vroom G. 2010. Pricing response to entry and agglomeration effects. Strategic Management Journal, 31 (3): 284-305.

McDougall P, Robinson, Jr. RB. 1990. New venture strategies: An empirical identification of eight 'archetypes' of competitive strategies for entry. Strategic Management Journal, 11 (6): 447-467.

McFadden D. 1974. Conditional logit analysis of qualitative choice behavior. In Frontiers in Econometrics, Zarembka P (ed). Academic Press: New York; 105-142.

Moskowitz TJ, Vissing-Jorgensen A. 2002. The returns to entrepreneurial investment: A private equity premium puzzle? American Economic Review, 92(4): 745-778.

Ocasio W. 1997. Toward and attention-based view of the firm. Strategic Management Journal, 18 (S1): 187-206.

Pleggenkuhle-Miles E, Peng MW. 2008. Embracing debates to advance global strategy research, in D Bergh and D Ketchen (eds.), Research Methodology in Strategy and Management, vol. 5. Oxford, UK: Emerald.

Poppo L, Zenger T. 1998. Testing alternative theories of the firm: Transaction cost, knowledgebased, and measurement explanations for make-or-buy decisions in information services. Strategic Management Journal, 19 (9): 853-877.

Porter ME. 1980. Competitive strategy. NY: Free Press.

Reuer JJ, Ragozzino R. 2006. Agency hazards and alliance portfolios. Strategic Management Journal, 27 (1): 27-43.

Sanders WG. Hambrick DC. 2007. Swinging for the fences. The effects of EXO stock options on company risk taking and performance. Academy of Management Journal, 50(5): 1055-1078.

Schulze WS, Lubatkin MH, Dino RN. 2002. Altruism, agency and the competitiveness of family firms. Journal of Managerial and Decision Economics, 23(4/5): 247-259.

Schulze WS, Lubatkin MH, Dino RN, Buchholtz AK. 2001. Agency relationships in family firms: Theory and evidence. Organization Science, 12(2): 99-116.

Scott Morton FM, Podolny JM. 2002. Love or money? The effects of owner motivation in the California wine industry. Journal of Industrial Economics, 50 (4): 431-456.

Shaver JM, Flyer F. 2000. Agglomeration economies, firm heterogeneity, and foreign direct investment in the United States. Strategic Management Journal 21 (12): 1175-1193.

Shleifer A, Vishny RW. 1991. Takeovers in the '60s and the '80s: evidence and implications. Strategic Management Journal, 12(Winter Special Issue): 51-59.

Short JC, McKelvie A, Ketchen Jr, DJ, Chandler GN. 2009. Firm and industry effects on firm performance: A generalization and extension for new ventures. Strategic Entrepreneurship Journal, 3 (1): 47-65.

Simon D. 2005. Incumbent pricing responses to entry. Strategic Management Journal, 26 (13): 1229-1248.

Simon HA. 1947. Administrative behavior, New York: The Free Press 
Sine WD, Lee BH. 2009. Tilting at windmills? The environmental movement and the emergence of the US wind energy sector. Administrative Science Quarterly, 54(1): 123-155.

Sklivas SD. 1987. The strategic choice of managerial incentives. Rand Journal of Economics, 18 (3): $452-458$.

Smith A. 1776. An inquiry into the nature and causes of the wealth of nations. Oxford University Press: Oxford (1976 reprint)

Smith KG, Ferrier WJ, Ndofor H. 2001. Competitive dynamics research: Critique and future directions. In Blackwell handbook of strategic management, Hitt MA, Freeman ER, Harrison JS (eds). Blackwell Publishing: Malden, MA: 315-361.

Thomsen S, Pedersen T. 2000. Ownership structure and economic performance in the largest European countries. Strategic Management Journal, 21 (6): 689-705.

Vickers J.1985. Delegation and the theory of the firm. Economic Journal, 95: 138-147.

Vroom G, Gimeno J. 2007. Ownership form, managerial incentives, and the intensity of rivalry. Academy of Management Journal, 50 (4): 901-922.

Wright P, Ferrris SP, Sarin A, Awasthi V. 1996. Impact of corporate insider, blockholder and institutional equity ownership on firm risk taking. Academy of Management Journal, 39(2): 441-463.

Wright P, Kroll M, Lado A, van Ness B. 2002. The structure of ownership and corporate acquisition strategies. Strategic Management Journal, 23 (1): 41-53.

World at Work. 2008. 2008-2009 salary budget survey. Washington, DC: World at Work. 
Table 1. Comparison of management-controlled and owner-controlled establishments

\begin{tabular}{lrrr}
\hline Measure & $\begin{array}{r}\text { Management- } \\
\text { Controlled } \\
\text { Establishments }\end{array}$ & $\begin{array}{r}\text { Owner- } \\
\text { Controlled } \\
\text { Establishments }\end{array}$ & Difference \\
\hline Establishment-Level Averages & & & \\
Capacity (Rooms) & 121.30 & 66.09 & $55.21 * *$ \\
Occupancy Rate (\%) & 59.15 & 50.60 & $8.55 * *$ \\
Average Daily Rate (US \$) & 60.59 & 49.88 & $10.71 * *$ \\
Segment (Ranges from 1-4) & 1.87 & 1.55 & $0.32 * *$ \\
\# of Hotels Owned by Owner & 15.22 & 1.04 & $14.17 * *$ \\
\% Franchise & 40.60 & 38.63 & 1.97 \\
\% Company-Owned & 35.88 & 0.00 & $35.88 * *$ \\
\% Independent & 23.49 & 61.37 & $-37.88 * *$ \\
& $n=1,490$ & $n=1,799$ & \\
Market-Level Averages & & & \\
Capacity (Rooms) & & & \\
Occupancy Rate (\%) & 531 & 418 & $113 * *$ \\
Average Daily Rate (US \$) & 54.79 & 52.07 & $2.72 * *$ \\
Segment (Ranges from 1-4) & 53.08 & 49.56 & $3.52 *$ \\
Market Concentration (HHI) & 1.61 & 1.52 & $0.09 *$ \\
Population & 0.46 & 0.51 & $-0.05 * *$ \\
Household Income & 22,941 & 20,214 & $2726.87 * *$ \\
Number of Establishments & 20,675 & 18,882 & $1793.26 *$ \\
& 5.37 & 4.67 & $0.70 *$ \\
\hline p & $n=518$ & $n=647$ & \\
\hline *0.05,** & & &
\end{tabular}

$* p<0.05, * * p<0.01$

Comparison as of period 17 (mid-point of data) 


\section{Table 2. Conditional logit models}

\begin{tabular}{|c|c|c|c|c|c|c|}
\hline & \multicolumn{3}{|c|}{ Choice Set: 250 Closest Markets } & \multicolumn{3}{|c|}{ Choice Set: 200 Closest Markets } \\
\hline & Model 1 & Model 2 & Model 3 & Model 4 & Model 5 & Model 6 \\
\hline \multirow[t]{2}{*}{ Market Occupany } & $0.020 * * *$ & $0.036 * * *$ & $0.034 * * *$ & $0.021 * * *$ & $0.038 * * *$ & $0.035 * * *$ \\
\hline & $(0.003)$ & $(0.005)$ & $(0.005)$ & $(0.003)$ & $(0.005)$ & $(0.005)$ \\
\hline \multirow[t]{2}{*}{ Owner-Controlled * Market Occupancy } & & $-0.031 * * *$ & $-0.029 * * *$ & & $-0.032 * * *$ & $-0.029 * * *$ \\
\hline & & $(0.006)$ & $(0.006)$ & & $(0.006)$ & $(0.006)$ \\
\hline \multirow[t]{2}{*}{ Owner Capacity * Market Occupancy } & & & 0.007 & & & $0.009+$ \\
\hline & & & $(0.004)$ & & & $(0.005)$ \\
\hline \multirow[t]{2}{*}{ Market Concentration } & $-0.686 * *$ & $-0.719 * * *$ & $-0.724 * * *$ & $-0.686 * *$ & $-0.720 * * *$ & $-0.728 * * *$ \\
\hline & $(0.211)$ & $(0.211)$ & $(0.211)$ & $(0.210)$ & $(0.210)$ & $(0.210)$ \\
\hline \multirow[t]{2}{*}{ Market Capacity } & $0.361 * * *$ & $0.357 * * *$ & $0.357 * * *$ & $0.360 * * *$ & $0.356 * * *$ & $0.355 * * *$ \\
\hline & $(0.051)$ & $(0.051)$ & $(0.051)$ & $(0.050)$ & $(0.050)$ & $(0.050)$ \\
\hline \multirow[t]{2}{*}{ Num. of Hotels of Same Chain } & $-1.521 * * *$ & $-1.527 * * *$ & $-1.529 * * *$ & $-1.524 * * *$ & $-1.529 * * *$ & $-1.538 * * *$ \\
\hline & $(0.207)$ & $(0.207)$ & $(0.207)$ & $(0.207)$ & $(0.207)$ & $(0.208)$ \\
\hline \multirow[t]{2}{*}{ Multi-Market Contact } & $0.114 * * *$ & $0.103 * *$ & $0.096 * *$ & $0.113 * * *$ & $0.102 * *$ & $0.093 * *$ \\
\hline & $(0.034)$ & $(0.034)$ & $(0.034)$ & $(0.034)$ & $(0.034)$ & $(0.034)$ \\
\hline \multirow[t]{2}{*}{ Rural } & -0.155 & -0.158 & -0.159 & -0.090 & -0.090 & -0.090 \\
\hline & $(0.100)$ & $(0.100)$ & $(0.100)$ & $(0.101)$ & $(0.101)$ & $(0.101)$ \\
\hline \multirow[t]{2}{*}{ Zip Code Retail Establishments } & $0.122+$ & $0.122+$ & $0.123+$ & $0.108+$ & $0.108+$ & $0.109+$ \\
\hline & $(0.063)$ & $(0.063)$ & $(0.063)$ & $(0.063)$ & $(0.063)$ & $(0.063)$ \\
\hline \multirow[t]{2}{*}{ Zip Code Gas Establishments } & $0.183 *$ & $0.188 *$ & $0.188 *$ & $0.221 * *$ & $0.225 * *$ & $0.225 * *$ \\
\hline & $(0.080)$ & $(0.080)$ & $(0.080)$ & $(0.080)$ & $(0.080)$ & $(0.080)$ \\
\hline \multirow[t]{2}{*}{ Zip Code Housing Units } & $0.392 * * *$ & $0.387 * * *$ & $0.386 * * *$ & $0.437 * * *$ & $0.431 * * *$ & $0.429 * * *$ \\
\hline & $(0.115)$ & $(0.113)$ & $(0.113)$ & $(0.119)$ & $(0.117)$ & $(0.117)$ \\
\hline \multirow[t]{2}{*}{ Zip Code Income } & $-0.339 * * *$ & $-0.341 * * *$ & $-0.342 * * *$ & $-0.366 * * *$ & $-0.364 * * *$ & $-0.363 * * *$ \\
\hline & $(0.090)$ & $(0.090)$ & $(0.090)$ & $(0.091)$ & $(0.092)$ & $(0.092)$ \\
\hline \multirow[t]{2}{*}{ Zip Code Population } & $-0.507 * * *$ & $-0.502 * * *$ & $-0.501 * * *$ & $-0.565 * * *$ & $-0.558 * * *$ & $-0.557 * * *$ \\
\hline & $(0.125)$ & $(0.124)$ & $(0.124)$ & $(0.130)$ & $(0.128)$ & $(0.128)$ \\
\hline Log-Likelihood & -5532.66 & -5518.38 & -5516.90 & -5298.27 & -5283.48 & -5281.47 \\
\hline Wald Chi-Squared & $674.25 * * *$ & $687.63 * * *$ & $687.32 * * *$ & $662.15 * * *$ & $676.51 * * *$ & 675.96 *** \\
\hline Number of Entries & 1,081 & 1,081 & 1,081 & 1,081 & 1,081 & 1,081 \\
\hline Average Alternatives per Entry & 235 & 235 & 235 & 188 & 188 & 188 \\
\hline Number of Observations & 254,563 & 254,563 & 254,563 & 203,670 & 203,670 & 203,670 \\
\hline
\end{tabular}

$+p<0.10,{ }^{*} p<0.05, * * p<0.01, * * * p<0.001$ 
Table 3. Exit hazard models

\begin{tabular}{|c|c|c|c|c|c|c|c|}
\hline & \multicolumn{3}{|c|}{ Cox Proportional Hazard Models } & 1 & \multicolumn{3}{|c|}{ Weibull Models } \\
\hline & Model 7 & Model 8 & Model 9 & 1 & Model 10 & Model 11 & Model 12 \\
\hline \multirow[t]{2}{*}{ Prior Unit Occupany } & $-0.062 * * *$ & $-0.067 * * *$ & $-0.067 * * *$ & | & $-0.058 * * *$ & $-0.063 * * *$ & $-0.063 * * *$ \\
\hline & $(0.004)$ & $(0.005)$ & $(0.005)$ & | & $(0.004)$ & $(0.004)$ & $(0.005)$ \\
\hline \multirow[t]{2}{*}{ Owner-Controlled } & $-0.602 * * *$ & $-1.116 * * *$ & $-1.117 * * *$ & | & $-0.64 * * *$ & $-1.136 * * *$ & $-1.14 * * *$ \\
\hline & $(0.127)$ & $(0.275)$ & $(0.277)$ & | & $(0.132)$ & $(0.267)$ & $(0.268)$ \\
\hline \multirow[t]{2}{*}{ Owner-Controlled * Prior Unit Occupancy } & & $0.013 *$ & $0.013 *$ & | & & $0.013 *$ & $0.013 *$ \\
\hline & & $(0.006)$ & $(0.006)$ & | & & $(0.006)$ & $(0.006)$ \\
\hline \multirow[t]{2}{*}{ Owner Capacity * Prior Unit Occupancy } & & & 0.000 & | & & & 0.000 \\
\hline & & & $(0.000)$ & | & & & $(0.000)$ \\
\hline \multirow[t]{2}{*}{ Market Occupancy } & $0.025 * * *$ & $0.024 * * *$ & $0.024 * * *$ & | & $0.039 * * *$ & $0.038 * * *$ & $0.038 * * *$ \\
\hline & $(0.007)$ & $(0.007)$ & $(0.007)$ & | & $(0.007)$ & $(0.007)$ & $(0.007)$ \\
\hline \multirow[t]{2}{*}{ Market Concentration } & $-0.774 *$ & $-0.751+$ & $-0.75+$ & | & $-0.685+$ & $-0.667+$ & $-0.666+$ \\
\hline & $(0.386)$ & $(0.386)$ & $(0.386)$ & । & $(0.395)$ & $(0.394)$ & $(0.395)$ \\
\hline \multirow[t]{2}{*}{ Market Capacity } & $-0.437 * * *$ & $-0.427 * * *$ & $-0.427 * * *$ & । & $-0.458 * * *$ & $-0.449 * * *$ & $-0.449 * * *$ \\
\hline & $(0.099)$ & $(0.100)$ & $(0.100)$ & | & $(0.100)$ & $(0.101)$ & $(0.101)$ \\
\hline \multirow[t]{2}{*}{ Num. of Hotels of Same Chain } & 0.571 & 0.575 & 0.575 & । & 0.576 & 0.577 & 0.576 \\
\hline & $(0.591)$ & $(0.595)$ & $(0.595)$ & | & $(0.597)$ & $(0.601)$ & $(0.600)$ \\
\hline \multirow[t]{2}{*}{ Multi-Market Contact } & 0.020 & 0.023 & 0.023 & | & 0.013 & 0.017 & 0.017 \\
\hline & $(0.048)$ & $(0.048)$ & $(0.048)$ & । & $(0.050)$ & $(0.050)$ & $(0.050)$ \\
\hline \multirow[t]{2}{*}{ Rural } & $-0.454 * *$ & $-0.445 * *$ & $-0.445 * *$ & | & $-0.429 * *$ & $-0.424 * *$ & $-0.424 * *$ \\
\hline & $(0.157)$ & $(0.156)$ & $(0.156)$ & | & $(0.163)$ & $(0.162)$ & $(0.162)$ \\
\hline \multirow[t]{2}{*}{ Owner Capacity } & $-0.194+$ & $-0.181+$ & -0.186 & | & $-0.211 *$ & $-0.199 *$ & -0.225 \\
\hline & $(0.102)$ & $(0.099)$ & $(0.141)$ & | & $(0.104)$ & $(0.101)$ & $(0.140)$ \\
\hline \multirow[t]{2}{*}{ Midscale Segment } & $-0.415 * *$ & $-0.398 *$ & $-0.398 *$ & | & $-0.462 * *$ & $-0.451 * *$ & $-0.451 * *$ \\
\hline & $(0.157)$ & $(0.158)$ & $(0.158)$ & | & $(0.160)$ & $(0.160)$ & $(0.161)$ \\
\hline \multirow[t]{2}{*}{ Upscale Segment } & $-0.892 * * *$ & $-0.853 * *$ & $-0.853 * *$ & । & $-0.897 * * *$ & $-0.862 * *$ & $-0.862 * *$ \\
\hline & $(0.264)$ & $(0.263)$ & $(0.263)$ & | & $(0.271)$ & $(0.268)$ & $(0.268)$ \\
\hline \multirow[t]{2}{*}{ Luxury Segment } & $-0.898 * *$ & $-0.881 * *$ & $-0.881 * *$ & | & $-0.917 * *$ & $-0.894 * *$ & $-0.895 * *$ \\
\hline & $(0.336)$ & $(0.335)$ & $(0.335)$ & | & $(0.345)$ & $(0.345)$ & $(0.345)$ \\
\hline \multirow[t]{2}{*}{ Zip Code Retail Establishments } & -0.019 & -0.022 & -0.022 & | & -0.037 & -0.04 & -0.04 \\
\hline & $(0.130)$ & $(0.131)$ & $(0.131)$ & | & $(0.135)$ & $(0.136)$ & $(0.136)$ \\
\hline \multirow[t]{2}{*}{ Zip Code Gas Establishments } & 0.203 & 0.204 & 0.204 & | & 0.209 & 0.21 & 0.21 \\
\hline & $(0.153)$ & $(0.153)$ & $(0.153)$ & | & $(0.155)$ & $(0.155)$ & $(0.155)$ \\
\hline \multirow[t]{2}{*}{ Zip Code Housing Units } & $0.891 * *$ & $0.888 * * *$ & $0.887 * * *$ & | & $0.962 * * *$ & $0.958 * * *$ & $0.957 * * *$ \\
\hline & $(0.271)$ & $(0.265)$ & $(0.266)$ & | & $(0.284)$ & $(0.278)$ & $(0.279)$ \\
\hline \multirow[t]{2}{*}{ Zip Code Income } & 0.092 & 0.103 & 0.103 & | & 0.051 & 0.063 & 0.064 \\
\hline & $(0.189)$ & $(0.189)$ & $(0.189)$ & | & $(0.195)$ & $(0.195)$ & $(0.195)$ \\
\hline \multirow[t]{2}{*}{ Zip Code Population } & $-0.898 * * *$ & $-0.895 * * *$ & $-0.894 * * *$ & | & $-0.975 * * *$ & $-0.972 * * *$ & $-0.971 * * *$ \\
\hline & $(0.227)$ & $(0.223)$ & $(0.224)$ & | & $(0.234)$ & $(0.230)$ & $(0.230)$ \\
\hline \multirow[t]{2}{*}{ Constant } & N/A & N/A & N/A & | & -1.817 & -1.729 & -1.728 \\
\hline & & & & 1 & $(2.254)$ & $(2.249)$ & $(2.249)$ \\
\hline Log-Likelihood & -2295.36 & -2293.23 & -2293.23 & | & -1203.2 & -1201.13 & -1201.12 \\
\hline Wald Chi-Squared & $376.538 * * *$ & $416.926 * * *$ & $418.596 * * *$ & | & $344.096 * * *$ & 385.937 *** & $388.955 * * *$ \\
\hline Number of Hotels & 4,149 & 4,149 & 4,149 & | & 4,149 & 4,149 & 4,149 \\
\hline Number of Exits & 306 & 306 & 306 & | & 306 & 306 & 306 \\
\hline Number of Observations & 105,037 & 105,037 & 105,037 & | & 105,037 & 105,037 & 105,037 \\
\hline
\end{tabular}

$+p<0.10, * p<0.05, * * p<0.01, * * * p<0.001$

Robust standard errors in parentheses, clustered on market 
Table 4. Fixed effects regression analysis of firm pricing

\begin{tabular}{|c|c|c|c|}
\hline & Model 13 & Model 14 & Model 15 \\
\hline Market Occupany & $\begin{array}{l}0.0021 \text { *** } \\
(0.0001)\end{array}$ & $\begin{array}{l}0.0025 \text { *** } \\
(0.0001)\end{array}$ & $\begin{array}{l}0.0022 \text { *** } \\
(0.0001)\end{array}$ \\
\hline Owner-Controlled & $\begin{array}{r}-0.0061 \\
(0.0048)\end{array}$ & $\begin{array}{l}0.0307 * * \\
(0.0111)\end{array}$ & $\begin{array}{r}0.0154 \\
(0.0115)\end{array}$ \\
\hline Owner-Controlled * Market Occupancy & & $\begin{array}{l}-0.0007 * * * \\
(0.0002)\end{array}$ & $\begin{array}{l}-0.0004 * \\
(0.0002)\end{array}$ \\
\hline Owner Capacity * Market Occupancy & & & $\begin{array}{l}0.0000 \text { *** } \\
(0.0000)\end{array}$ \\
\hline Market Concentration & $\begin{array}{r}-0.0098 \\
(0.0208)\end{array}$ & $\begin{array}{r}-0.0102 \\
(0.0208)\end{array}$ & $\begin{array}{r}-0.0095 \\
(0.0208)\end{array}$ \\
\hline Market Capacity & $\begin{array}{r}-0.0060 \\
(0.0079)\end{array}$ & $\begin{array}{r}-0.0056 \\
(0.0079)\end{array}$ & $\begin{array}{r}-0.0057 \\
(0.0079)\end{array}$ \\
\hline Num. of Hotels of Same Chain & $\begin{array}{l}-0.0259+ \\
(0.0149)\end{array}$ & $\begin{array}{l}-0.0253+ \\
(0.0150)\end{array}$ & $\begin{array}{l}-0.0251+ \\
(0.0150)\end{array}$ \\
\hline Multi-Market Contact & $\begin{array}{l}-0.0017 \text { * } \\
(0.0008)\end{array}$ & $\begin{array}{l}-0.0017 \text { * } \\
(0.0008)\end{array}$ & $\begin{array}{l}-0.0015 * \\
(0.0007)\end{array}$ \\
\hline Rural & $\begin{array}{l}-0.0318 \text { ** } \\
(0.0114)\end{array}$ & $\begin{array}{l}-0.0315 * * \\
(0.0114)\end{array}$ & $\begin{array}{l}-0.0313 \text { ** } \\
(0.0114)\end{array}$ \\
\hline Owner Capacity & $\begin{array}{r}-0.0000 \\
(0.0000)\end{array}$ & $\begin{array}{r}-0.0000 \\
(0.0000)\end{array}$ & $\begin{array}{l}-0.0000 * * * \\
(0.0000)\end{array}$ \\
\hline Franchised Hotel & $\begin{array}{l}0.0674 \text { *** } \\
(0.0113)\end{array}$ & $\begin{array}{l}0.0675 \text { *** } \\
(0.0113)\end{array}$ & $\begin{array}{l}0.0677 \text { *** } \\
(0.0113)\end{array}$ \\
\hline Company-Owned Hotel & $\begin{array}{l}0.0784 \text { *** } \\
(0.0151)\end{array}$ & $\begin{array}{l}0.0778 \text { *** } \\
(0.0152)\end{array}$ & $\begin{array}{l}0.0792 \text { *** } \\
(0.0151)\end{array}$ \\
\hline Constant & $\begin{array}{l}3.6887 * * * \\
(0.0539)\end{array}$ & $\begin{array}{l}3.6626 \text { *** } \\
(0.0539)\end{array}$ & $\begin{array}{c}3.6796 \text { *** } \\
(0.0539)\end{array}$ \\
\hline Fixed Establishment Effects & YES & YES & YES \\
\hline Fixed Segment Effects & YES & YES & YES \\
\hline Fixed Time Effects & YES & YES & YES \\
\hline Number of Observations & 108,153 & 108,153 & 108,153 \\
\hline Number of Hotels & 4,249 & 4,249 & 4,249 \\
\hline F-Value & $109.920 * * *$ & $106.804 * * *$ & $105.748 * * *$ \\
\hline R-Sq-Between & 0.5937 & 0.5919 & 0.594 \\
\hline R-Sq-Within & 0.0614 & 0.0621 & 0.0634 \\
\hline
\end{tabular}

$+p<0.10, * p<0.05, * * p<0.01, * * * p<0.001$

Robust standard errors in parentheses, clustered on unit 


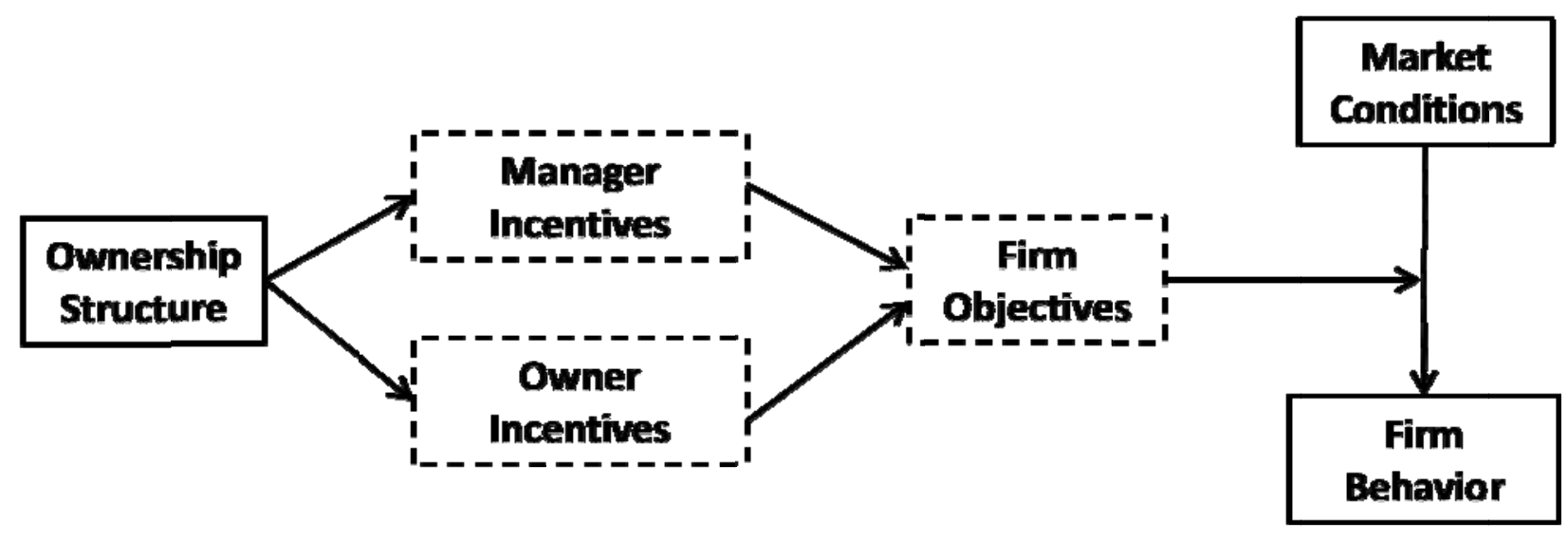

Dotted lines indicate unobserved constructs

Figure 1. The role of ownership structure in influencing firm behavior 


\section{Panel A - The Impact of Increasing Market Occupancy on Log Odds of Entry}

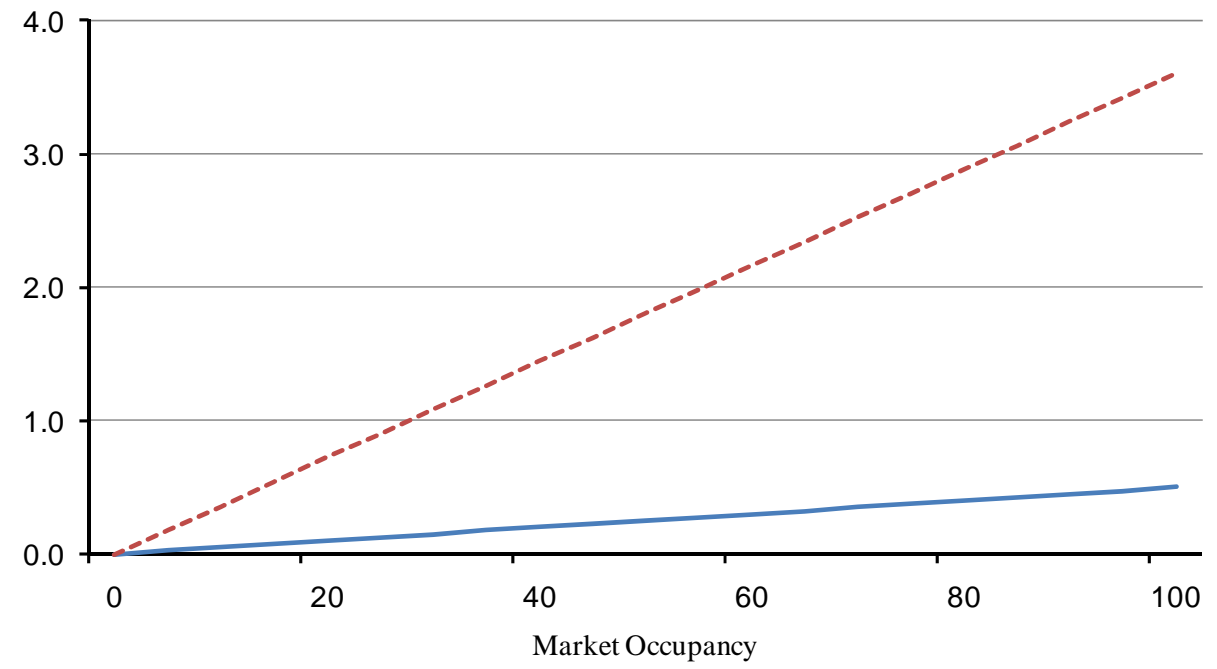

- Owner-Controlled --- Management-Controlled

Note: figure created from results of Model 2

Panel B - The Impact of Increasing Unit Occupancy on Probability of Exit within One Year

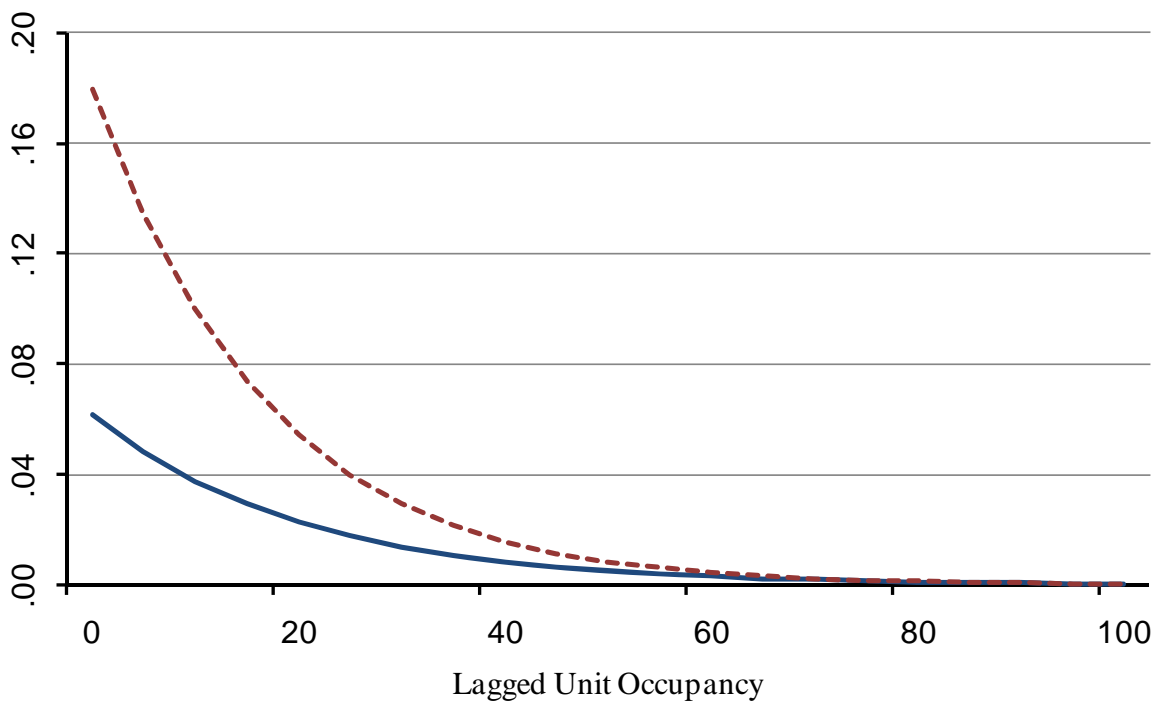

-Owner-Controlled --- Management-Controlled

Note: figure created from results of Model 9

Figure 2. Moderating effects of ownership structure on entry and exit behaviors 